IRSTI 06.52.01

UDC 331.538 .2

https://doi.org/10.46914/1562-2959-2021-1-2-191-198

\author{
R.T. SERGALIYEVA, ${ }^{\text {* }}$ \\ PhD student. \\ *e-mail: Sergalieva89@mail.ru \\ R.O. BUGUBAYEVA, \\ c.e.s., professor. \\ e-mail: prur@keu.kz \\ L.A. TALIMOVA, ${ }^{1}$ \\ d.e.s., professor. \\ e-mail: Laz.tal@mail.ru \\ ${ }^{1}$ Karaganda economic university \\ of Kazpotrebsoyuz, Kazakhstan, Karaganda
}

\title{
COMPETENCE-BASED APPROACH IN THE PROFESSIONAL DEVELOPMENT OF CIVIL SERVANTS
}

\begin{abstract}
In the current context, competencies are becoming a universal measure of the success and effectiveness of human activity in any profession. The civil service of Kazakhstan is promising and trainable. Today, an important task is to train civil servants of the "new generation". As a global information world, digital transformation requires them to understand the new specifics of civil service and improve their skills and competencies. Therefore, the competence-based approach in the professional development of civil servants that is becoming increasingly relevant. It motivates civil servants to further advance in their professional careers, and is also the basis for the formation of information support for the management of civil service personnel in almost all countries. The competence-based approach has recently been declared as the starting point of all personnel management activities. It can be used to select personnel, evaluate the quality of their work, and build a career and training system. In this article, the authors give the concept of the competence approach, professional development of civil servants. The purpose of this study is to study the features of the organization of professional development of civil servants in foreign countries, to compare the composition of the competencies of the presented models for further development of ways to reform the system of professional training of civil servants in Kazakhstan. The analysis of the main components of the models of competencies of civil servants in different countries is presented. The development of professional competencies of civil servants should acquire a strategic character, be designed for the future. The research methodology is based on the application of the process approach, historical analysis, modeling and classification methods, and the method of scientific generalizations.
\end{abstract}

Key words: civil service, civil servant, competency, competence, professionalism, personnel, policy.

\section{Introduction}

One of the main factors of ensuring the competitiveness of Kazakhstan is the transition to the strategic stage of development. The key to the stable and intensive growth of Kazakhstan is a professional state apparatus. The socio-economic and political stability of society depends on the professionalism of civil servants, their initiative, and professional training.

The development of the digital space in the civil service, the introduction of e-government requires new skills from civil servants, in particular digital ones. In this regard, the competence approach has become one of the main tools for managing civil servants. The changed socio-economic conditions, new market requirements for specialists have caused the need for competence-based professional education. Changes are needed in the work with personnel in the civil service, a transition from qualifications to competencies that reflect business and personal qualities is required. 


\section{Main provisions}

The competence approach has its own structure: name, definition, set of behavioral indicators. So far, the works of domestic and foreign researchers have accumulated a certain theoretical and practical material on the disclosure of the essence of the competence approach.

The founders of the competence approach were such scientists as D. McClelland (1970), R. Boyatzis (1982), L. Spencer (1993) [1]. The term "competence" has a foreign origin, so its interpretation largely depends on the language from which it was translated. For example, in French, the word "competence" has two meanings - competence and awareness; and in English - three: ability, or skill, competence, jurisdiction. Translated from Latin, it means belonging by right or to correspond. As for the Chinese interpretation of the concept of "competence", it should be noted that it is quite applicable to civil service, since it is translated as "to be worthy of the Path" (Taoism) or "to be worthy of Service" (Confucianism). The Head of State of Kazakhstan has repeatedly noted that "Civil servants of the new generation should not forget about serving the people, the key indicator of the activities of civil servants should be the quality of services to the population, civil servant-from the word "serve" [2].

Let us dwell on the main characteristics of the competence-based approach. I.A. Zimnaya differentiates the concepts of "competence" and "competency" on the basis of "potential-actual". If "competence" performs the function of "potential", then "competency" is understood by it as an actual, formed personal quality, as a knowledge-based, intellectually and personally determined social and professional characteristic of a person [3].

A. A. Verbitsky as the basis for the separation of the concepts of "competence" and "competency" suggests the objectivity and subjectivity of the conditions that determine the quality of an individual's activity. Competence is a set of objective criteria that determine the possibilities and limits of the implementation of an individual's competency. Competency is considered as a set of knowledge, skills and abilities that allow its subject to effectively solve issues and perform the necessary actions in any area of life [4].

S.L. Troyanskaya notes, "The competence-based approach is the priority orientation of education towards its results: the formation of the necessary general cultural and professional competencies, self-determination, socialization, the development of individuality and self-actualization" [5].

Competency is considered as the final result, indicating the ability of the specialist to achieve the goal. It contains the following elements: subject and operational knowledge; skills, abilities; ability and readiness to use them in activities; responsibility for the results of this activity [6-7].

The British psychologist John Raven interpreted competency as a specific ability that is necessary for the effective performance of a specific action in a specific subject area and includes highly specialized knowledge - a special kind of subject skills, ways of thinking, as well as an understanding of responsibility for one's actions. Be a competent scientist, teacher, firefighter, parent, or government employee in the opinion of J.Raven, means to have a set of specific competencies of different levels: to be deeply knowledgeable in the subject, to observe, to write business letters, to raise questions independently, to prove one's own rightness, to cope with interpersonal conflicts [8].

According to Yakhontova E. S., "competence is an attribute of a person that determines the scope of his knowledge, skills, experience and qualifications. The employee is competent-this means that he is able to do a certain job. It is not a fact that he will do it and will do it well. Competence is an attribute of the company, the behavior of an employee, which reflects his competency and attitude to work." [9].

Thus, the main content of the competence-based approach is the educational component that forms professional competence, expressed in the acquired knowledge, skills and abilities. The introduction of this approach is caused by socio-economic and pedagogical prerequisites. This is the reaction of vocational education to the changed socio-economic conditions that impose new requirements for specialists.

Therefore, the process of forming the communicative competence of civil servants should be built on the basis of a competence-based approach. Since it determines the orientation of the training of civil servants to the development of personal qualities, it develops the creative potential, as well as the cognitive abilities of a civil servant to achieve specific results. The competence-based approach is currently determined by the necessary element in the professional development of civil servants. 
The professional competencies of a civil servant have social and professional significance. The basis of professional competencies of civil servants is their qualifications, as well as the level of training.

\section{Materials and methods}

The effectiveness of the work of the state apparatus is determined by the selection of personnel, their professional training, business and human qualities, and the ability to quickly and efficiently perform their functional duties. Thus, according to G. V. Atamanchuk, "personnel training has two aspects: the first is related to primary training, which is necessary for filling certain positions with personnel, and the second is related to improving the skills of officials" [10].

The main tasks of professional training are the training of qualified specialists who are able to perform their official duties and improve the professional qualifications of civil servants. Professional training is conducted for the purpose of acquiring theoretical knowledge, as well as practical mastering and consolidation of skills in the performance of official duties. Retraining and advanced training of civil servants is a key element of the development of the human capital of the civil service.

If the recruitment, selection of employees is carried out at a high level, in accordance with the parameters of the models of workplaces, people with the necessary knowledge and skills are hired, then the main factor ensuring the development of the state apparatus becomes personnel training.

Competence management tools are competence models and professional standards. They are designed to determine the requirements for employees and job seekers, establish criteria for evaluating human resources and the results of their work, develop professionalism and potential, and improve the quality of work.

For the first time, competence models were widely used in foreign government organizations in the United Kingdom and the United States. Gradually, as the models of competencies appeared, legislative acts and normative documents fixing the principles of the work of civil servants began to be approved. These included the basic values of public service and the role of employees themselves in shaping a developing society [11].

The foreign practice of forming the apparatus of civil servants is conditioned by the presence of established requirements for candidates for positions set out in national models of competencies, including specialized knowledge and skills from certain subject areas, such as knowledge of legislation, financial analysis skills, office management, as well as the presence of competencies that reflect individual personality characteristics.

Let's consider the competence models of civil servants in the United States, Great Britain, and France. The data is shown in table 1.

Table 1 - The main components of the models of competencies of civil servants

\begin{tabular}{|l|l|l|}
\hline \multicolumn{1}{|c|}{ Country } & \multicolumn{1}{|c|}{ Brief description } & \multicolumn{1}{c|}{ Model competencies } \\
\hline The USA & $\begin{array}{l}\text { It is characterized by decentralization, } \\
\text { multi-level programs and their } \\
\text { relationship }\end{array}$ & $\begin{array}{l}\text { 1) Core competencies: } \\
\text { Interpersonal communication skills } \\
\text { Continuous education }\end{array}$ \\
\hline & $\begin{array}{l}\text { with training programs in the field } \\
\text { of business. There is a Center for } \\
\text { leadership development, official } \\
\text { website for training and professional } \\
\text { development of the US Federal } \\
\text { government, the Federal Leadership } \\
\text { Institute, the National of US Civil } \\
\text { Service Institutions. }\end{array}$ & $\begin{array}{l}\text { Oral communication } \\
\text { Written communications }\end{array}$ \\
& $\begin{array}{l}\text { Honesty/integrity } \\
\text { Focus on public services } \\
\text { 2) Key executive qualifications and Leadership } \\
\text { competencies: } \\
\text { Change management } \\
\text { Managing people } \\
\text { Result orientation } \\
\text { Managerial capacity } \\
\text { The establishment of associations }\end{array}$ \\
\hline
\end{tabular}


Continuation of table 1

\begin{tabular}{|c|c|c|}
\hline The UK & $\begin{array}{l}\text { The competence model is the same for } \\
\text { all civil servants. It puts the following } \\
\text { values of the civil service: Integrity, } \\
\text { integrity, impartiality, objectivity, and } \\
\text { leadership. There is a Civil Service } \\
\text { College; a Civil Service Learning } \\
\text { website; and a Fast Stream program. }\end{array}$ & $\begin{array}{l}\text { 1) Professional Skills for Government: the } \\
\text { individual potential of the employee; information } \\
\text { management skills: effective communication, } \\
\text { information analysis, IT competence. } \\
\text { 2) SCS Competence Framework-designed for senior } \\
\text { managers: Leadership qualities; management skills. } \\
\text { There is a General program consisting of three } \\
\text { blocks: } \\
\text { 1. Key skills: customer service, project } \\
\text { management, finance and information technology } \\
\text { skills. } \\
\text { 2. Work in the civil service: specific skills: } \\
\text { conducting briefings, preparing documents, having } \\
\text { a legal consciousness. } \\
\text { 3. Leadership and Management Improvement - the } \\
\text { skills needed to lead, manage people and businesses } \\
\text { at all levels of the civil service, as well as change } \\
\text { management topics. }\end{array}$ \\
\hline France & $\begin{array}{l}\text { The system of training civil servants } \\
\text { is centralized and has a multi-level } \\
\text { structure. There are more than } 150 \\
\text { administrative schools. } 3 \text { main } \\
\text { educational institutions that prepare } \\
\text { candidates for higher administrative } \\
\text { positions: } \\
\text { ENA, INET and EHESP } \\
\text { A special educational institution, the } \\
\text { National School of Administration } \\
\text { (ENA), trains personnel for the civil } \\
\text { service. }\end{array}$ & $\begin{array}{l}\text { "Initial training" + "Lifelong training": } \\
\text { 1) schools that provide training } \\
\text { for specialties that require special } \\
\text { skills (for the police, financial services, } \\
\text { customs, judges and prosecutors) } \\
\text { 2) schools that provide training in } \\
\text { the basics of administrative } \\
\text { management (legal, budgetary } \\
\text { technologies, management and management of } \\
\text { physical resources) } \\
\text { Training at the School of Public Administration } \\
\text { includes: } \\
\text { A seminar in the field of public sector management; } \\
\text { Interdepartmental trainings; } \\
\text { Career mobility; } \\
\text { Post-Graduate Course in European Studies. } \\
\text { In general regulations, the criteria for evaluating the } \\
\text { effectiveness of civil } \\
\text { servants are formulated in an exclusively general } \\
\text { sense: } \\
\text { General skills and professional knowledge; } \\
\text { Relationships with other employees and behavior, } \\
\text { understanding of the mission of public service, } \\
\text { relations with management, degree of socialization, } \\
\text { ability to work in a team; Sociability; } \\
\text { Efficiency and effectiveness in the performance of } \\
\text { official duties; Ability to manage; Ability to perform } \\
\text { new functions. }\end{array}$ \\
\hline
\end{tabular}

\section{Discussion}

The Unified Competence Framework has been implemented in Kazakhstan since 2019. It consists of 11 competencies, grouped into 4 blocks, corresponding to the characteristics of the professional state apparatus and the personal qualities of employees. The unified framework of competencies is aimed at ensuring that the selection and promotion in the civil service are carried out according to the same values and principles to which any civil servant should be committed, regardless of the level of his position and the scope of his activities. Thus, the competence-based approach is implemented both in the selection and in the integrated certification of civil servants, in order to identify the personal competencies of each employee. 
Integrity, consumer orientation, responsibility, initiative, and stress tolerance are the basic necessary set of qualities for a civil servant, which all candidates must meet, regardless of the level of the position being applied for. Additional competencies are: for executive positions: self-development, efficiency, cooperation and interaction, activity management. For managers of lower ranks: decisionmaking, leadership, collaboration and interaction, efficiency and self-development. For mid-level managers: strategic thinking, change management, leadership, decision-making, performance management, cooperation and collaboration. For higher education: positions of the corps "A": along with the specified competencies, it is necessary to have a system management.

The civil service system of Kazakhstan is gradually being reoriented primarily to meet the needs and demands of citizens. Professionalism and competence are considered as a set of subjects and objects of activity of a civil servant established by the regulations, the rights and obligations that are fixed in legislation, the powers that a particular state management body or official has, as defined by the Constitution, laws, resolutions and other normative legal acts. Thus, professionalism, continuity of training, development of the necessary competencies of civil servants are designated as the basic principles of civil service.

\section{Results}

Summing up, we note that a comparison of the competencies of the presented models shows that a significant part of them are general behavioral competencies. The analysis of foreign experience shows that in many countries the basis for the development of professional development programs are clusters of competencies, as well as models of key qualifications. In different countries, the competence models are diverse in content, but they have similar elements: change management, strategic thinking, leadership skills, achieving results, communication skills, and interpersonal relationships.

In all the countries considered, the system of distance education is widely developed, which allows you to complete advanced training on the job, which significantly saves time and financial costs. It should also be noted that the coronavirus pandemic has shown us that remote technologies are an effective way to organize training during the epidemic.

In most countries, one of the main principles of training civil servants is constant continuous professional development. For many positions, individual development plans are drawn up. This allows government agencies to plan and conduct professional development not only on existing subjects, but also on specific ones that meet the needs of a particular department or division. It should also be noted that professional development in these countries is carried out individually, employees have the opportunity to choose programs. National models of civil servants' competence allow timely identification of skills gaps in civil servants.

\section{Conclusion}

The content of the Kazakhstan competence framework is largely similar to the content of the models of foreign countries. It complies with the OECD (Organization for Economic Co-operation and Development) standards and best foreign practices.

The use of a single competence framework allows for an objective assessment of the compliance of each civil servant with professional competencies, and also allows you to create an order for professional development of civil servants, taking into account the development of specific professional competencies necessary for each employee. However, it should be noted that national competence models, including the Kazakhstan competence framework, do not fully take into account the basic requirements for knowledge and skills in the field of information and communication technologies. In the digital economy, it is impossible to successfully solve a task of a certain category, to achieve a given result without the key competencies of the digital economy, such as: communication and cooperation in the digital environment; self-development in conditions of uncertainty; information and data management; critical thinking in the digital environment. 
The introduction of a competence-based approach in the civil service of the Republic of Kazakhstan allows you to distribute all employees by levels for further planning and support of their professional development and career growth.

The competencies of civil servants can be defined as a set of behavioral models, the level of competencies is considered as an indicator that determines the professional suitability of a civil servant, his ability to carry out official activities, both in regular and in extreme conditions.

Highly professional personnel have always been the key to the competitiveness of the state. And the overall successful implementation of State policy depends on the ability of each civil servant to effectively perform their functional duties and their ability to provide high-quality services to the population. It is obvious that today higher education should provide the country with specialists who are able to think critically, who are well-informed and deeply motivated. The competence-based approach undoubtedly brings modern domestic education in line with the real conditions and prospects, motivates civil servants to further advance in professional career growth.

\section{REFERENCES}

1 Дудаев Г.С-Х. Компетентностный подход и понятие «управленческая компетентность» в процессе профессиональной подготовки будущих специалистов государственного управления // Фундаментальные исследования. - 2014. - № 6-2. - С. 350-354.

2 https://tengrinews.kz/kazakhstan_news/kakimi-kompetentsiyami-doljen-obladat-idealnyiy-310479/

3 Зимняя И.А. Ключевые компетенции - новая парадигма результата современного образования / И.А. Зимняя // Эйдос. - 2009. - № 5. - С. 13-17.

4 Вербицкий А.А. Личностный и компетентностный подходы в образовании: проблемы интеграции. - М.: Логос, 2009. - 339 с.

5 Троянская С.Л. Основы компетентностного подхода в высшем образовании: учебное пособие. Ижевск: Издательский центр «Удмуртский университет», 2016. - 176 с.

6 Волкова О.В. Научно-методические основы формирования значимых умений и компетенций преподавателя музыкальных дисциплин: автореф. дис. - Павлодар, 2010.

7 Компетентностный подход в педагогическом образовании / под ред. В.А. Козырева, Н.Ф. Радионовой. - СПб.: Изд-во РГПУ, 2005. - 392 с.

8 Равен Дж. Компетентность в современном обществе: выявление, развитие и реализация / Пер. с англ. - М., «Когито-Центр», 2002. - 396 с.

9 Атаманчук Г.В. Сущность государственной службы: история, теория, закон, практика. Монография / Г.В. Атаманчук - М.: Закон, 2013. - 272 с.

10 Кудрявцева Е.И. Менеджмент компетенций в системе государственной гражданской службы // Управленческое консультирование. - 2013. - № 6(54). - С. 22-31.

11 Яхонтова Е.С. Компетентностный подход в управлении человеческими ресурсами. - Москва, 2014. - C. 9.

12 Брыкова С.С. Сравнение зарубежного опыта организации и правового регулирования государственной службы (на примере Франции) / С.С. Брыкова. - Текст: непосредственный // Молодой ученый. - 2019. - № 2 (240). - С. 107-109.

\section{REFERENCES}

1 Dudaev G.S-H. (2014) Kompetentnostnyj podhod i ponjatie «upravlencheskaja kompetentnost'» v processe professional'noj podgotovki budushhih specialistov gosudarstvennogo upravlenija // Fundamental'nye issledovanija, No. 6-2, pp. 350-354.

2 https://tengrinews.kz/kazakhstan_news/kakimi-kompetentsiyami-doljen-obladat-idealnyiy-310479/

3 Zimnjaja I.A. (2009) Kljuchevye kompetencii - novaja paradigma rezul'tata sovremennogo obrazovanija / I.A. Zimnjaja // Jejdoc, No. 5, pp. 13-17.

4 Verbickij A.A. (2009) Lichnostnyj i kompetentnostnyj podhody v obrazovanii: problemy integracii. M.: $\log 0$, $339 \mathrm{p}$.

5 Trojanskaja S.L. (2016) Osnovy kompetentnostnogo podhoda v vysshem obrazovanii: uchebnoe posobie. - Izhevsk: Izdatel'skij centr "Udmurtskij universitet", $176 \mathrm{p}$. 
6 Volkova O.V. (2010) Nauchno-metodicheskie osnovy formirovanija znachimyh umenij i kompetencij prepodavatelja muzykal'nyh disciplin: avtoref. dis. Pavlodar.

7 Kompetentnostnyj podhod v pedagogicheskom obrazovanii / pod red. V.A. Kozyreva, N.F. Radionovoj.SPb.: Izd-vo RGPU, 2005, 392 p.

8 Raven Dzh. (2002) Kompetentnost' v sovremennom obshhestve: vyjavlenie, razvitie i realizacija / Per. s angl. - M., «Kogito-Centr», 396 p.

9 Atamanchuk G.V. (2013) Sushhnost' gosudarstvennoj sluzhby: istorija, teorija, zakon, praktika. Monografija / G.V. Atamanchuk - M.: Zakon, 272 p.

10 Kudrjavceva E.I. (2013) Menedzhment kompetencij v sisteme gosudarstvennoj grazhdanskoj sluzhby // Upravlencheskoe konsul'tirovanie, No. 6(54), pp. 22-31.

11 Jahontova E.S. (2014) Kompetentnostnyj podhod v upravlenii chelovecheskimi resursami, Moskva, pp. 9.

12 Brykova S.S. (2019) Sravnenie zarubezhnogo opyta organizacii i pravovogo regulirovanija gosudarstvennoj sluzhby (na primere Francii) / S.S. Brykova. - Tekst: neposredstvennyj // Molodoj uchenyj, No. 2(240), pp. 107-109.

\author{
Р.Т. СЕРГАЛИЕВА, ${ }^{1 *}$ \\ докторант. \\ *e-mail: Sergalieva89@mail.ru \\ P.О. БҰҒЫБАЕВА, \\ э.ґ.К., профессор. \\ e-mail: prur@keu.kz \\ Л.А. ТАЛИМОВА, ${ }^{1}$ \\ э.Ғ.Д., профессор. \\ e-mail: Laz.tal@mail.ru \\ Қазақстан, Қарағанды қ.
}

${ }^{1}$ Қазтұтынуодағы Қарағанды университеті,

\title{
МЕМЛЕКЕТТІК ҚЫЗМЕТШІЛРДІҢ КӘСІБИ ДАМУЫНДАҒЫ ҚҰЗЫРЕТТІЛІК ТӘСІЛ
}

\begin{abstract}
Андатпа
Қазіргі жағдайда құзіреттіліктер кез-келген мамандықтағы адам қызметінің сәттілігі мен тиімділігінің әмбебап өлшеуішіне айналады. Қазақстан Республикасының мемлекеттік қызметі болашағы зор, қызметшілерді әрдайым оқытқан жөн. Бүгінгі таңда біздің елімізде де мемлекеттік қызметшілерді «жаңа тұрпатта» оқыту маңызды міндет болып табылады. Жаһандық ақпараттық әлем, цифрлық трансформация олардан мемлекеттік қызметтің жаңа ерекшелігін түсінуді және өз дағдылары мен құзыреттерін жетілдіруді талап етеді. Сондықтан мемлекеттік қызметшілердің кәсіби дамуындағы құзыреттілік тәсіл өзекті бола түсуде. Ол мемлекеттік қызметшілерді кәсіби мансаптық өсуді одан әрі ілгерілетуге ынталандырады, сондай-ақ іс жүзінде барлық елдерде мемлекеттік қызмет кадрларын басқаруды ақпараттық қолдауды қалыптастырудың негізі болып табылады. Құзыреттілік тәсіл соңғы уақытта персоналды басқару бойынша барлық қызметтің бастапқы нүктесі ретінде жарияланды. Оның көмегімен кадрларды іріктеуді жүзеге асыруға, олардың жұмысының сапасын бағалауға, мансап пен оқыту жүйесін құруға болады. Бұл мақалада авторлар құзыреттілік тәсіл, мемлекеттік қызметшілердің кәсіби дамуы туралы түсінік береді. Аталған зерттеудің мақсаты мемлекеттік қызметшілердің шет елдерде кәсіби дамуын ұйымдастыру ерекшеліктерін зерделеу, Қазақстанда мемлекеттік қызметшілердің кәсіби даярлығы жүйесін реформалау жолдарын одан әрі әзірлеу үшін ұсынылған модельдердің құзыреттер құрамын салыстыру болып табылады. Әр түрлі елдердің мемлекеттік қызметшілерінің құзыреттілік модельдерінің негізгі компоненттеріне талдау ұсынылған. Мемлекеттік қызметшілердің кәсіби құзыреттерін дамыту стратегиялық сипатқа ие болуға, перспективаға есептелуге тиіс. Зерттеу әдістемесі технологиялық тәсілді, тарихи талдауды, модельдеу және жіктеу әдістерін, ғылыми жалпылау әдісін қолдануға негізделген.
\end{abstract}

Тірек сөздер: мемлекеттік қызмет, мемлекеттік қызметші, құзыреттер, құзыреттілік, кәсібилік, кадрлар, саясат. 


\author{
Р.Т. СЕРГАЛИЕВА, ${ }^{1 *}$ \\ докторант. \\ *e-mail: Sergalieva89@mail.ru \\ P.O. БУГУБАЕВА, ${ }^{1}$ \\ к.э.н., профессор. \\ e-mail: prur@keu.kz \\ Л.А. ТАЛИМОВА, ${ }^{1}$ \\ д.э.н., профессор. \\ e-mail: Laz.tal@mail.ru \\ Казахстан, г. Караганда
}

${ }^{1}$ Карагандинский университет Казпотребсоюза,

\title{
КОМПЕТЕНТНОСТНЫЙ ПОДХОД В ПРОФЕССИОНАЛЬНОМ РАЗВИТИИ ГОСУДАРСТВЕННЫХ СЛУЖАЩИХ
}

\begin{abstract}
Аннотация
В современных условиях компетенции становятся универсальным измерителем успешности и эффективности деятельности человека в любой профессии. Государственная служба Казахстана перспективна и обучаема. На сегодняшний день важной задачей является обучение госслужащих «новой генерации». В глобальном информационном мире цифровая трансформация требует понимания новой специфики государственной службы и совершенствования своих навыков и компетенций. Поэтому именно компетентностный подход в профессиональном развитии государственных служащих приобретает все большую актуальность. Он мотивирует государственных служащих на дальнейшее продвижение в профессиональном карьерном росте, а также является основой формирования информационной поддержки управления кадрами государственной службы практически во всех странах. Компетентностный подход декларируется в последнее время как отправная точка всей деятельности по управлению персоналом. С его помощью можно осуществлять отбор кадров, оценивать качество их работы, строить систему карьеры и обучения. В данной статье авторами дается понятие компетентностного подхода, профессионального развития государственных служащих. Целью данного исследования является изучение особенностей организации профессионального развития государственных служащих в зарубежных странах, сравнение состава компетенций представленных моделей для дальнейшей разработки путей реформирования системы профессиональной подготовки государственных служащих в Казахстане. Представлен анализ основных компонентов моделей компетенций государственных служащих различных стран. Развитие профессиональных компетенций государственных служащих должно приобрести стратегический характер, быть рассчитанным на перспективу. Методология исследования основывается на применении процессного подхода, исторического анализа, методов моделирования и классификации, метода научных обобщений.
\end{abstract}

Ключевые слова: государственная служба, государственный служащий, компетенции, компетентность, профессионализм, кадры, политика. 